\title{
UNIVERSITY EDUCATION FOR CIVIL AVIATION IN THE CR ACCORDING TO EUROPEAN STANDARDS
}

\author{
L. Kulčák \\ Faculty of Transportation Sciences, Czech Technical University in Prague. E-mail: kulcak@fd.cvut.cz \\ Received 2005-01-03, accepted 2006-12-11
}

Ludvík KULČÁK, Prof Dr Habil

Date and place of birth: 1945 in Novy Hrozenkov, Czechoslovak Republic.

Education: 1967 - Technical University of Brno, specialisation Technical cybernetics; 1974 - postgraduate course in systems engineering; 1978 - science degree and title of Candidate of Science - CSc. (Dr.) from Brno Military

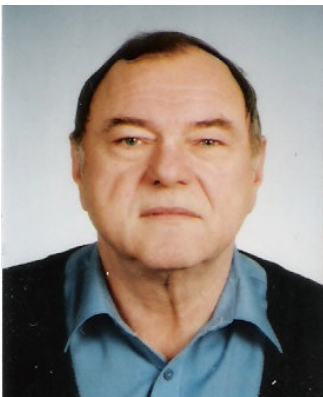
Academy, specialisation technical cybernetics. 1992 - pedagogical degree and titles - Associate Professor - doc. from the University of Transport and Communications (UTC) Žilina, specialisation transport technical and technology; 1995 - Professor - Prof. from the University of Transport and Communications Žilina, specialisation transport technical and technology.

Affiliations and functions: A senior researcher at the Czechoslovak Traffic Airport Administration (till 1977), Chief of Research and Development Department at the Air Traffic Control of the ČSSR (till 1991), lecturer at the Department of Air Transport, Faculty of Traffic and Transport Economy and Telecommunications, UTC Žilina (till 1992), Associate professor at the Department of Air Transport, UTC Žilina (till 1995), professor at the Department of Air Transport, University of Žilina (till 2000). Beginning in 1993, participated in the teaching programme of the Institute of Aerospace Engineering, TU of Brno (till 2001). Since 2001 has been working in Faculty of Transportation Sciences at CTU Prague. Established Department of Air Transport at CTU Prague.

Present position: professor at Czech Technical University in Prague, Faculty of Transportation Sciences, Department of Air Transport; Horská 3, 12803 Praha 1, Czech Republic; tel.: + 420-224 359 182, private: + 420-541 225489.

\begin{abstract}
The article describes the educational system in the Faculty of Transportation Sciences at Czech Technical University in Prague. The university education is structured according to European standards. There are three levels of education: bachelor's degree programme, master's degree programme and doctoral degree programme. The article offers profiles of the graduates from all the majors of the Department of Air Transport.
\end{abstract}

Keywords: bachelor, Czech Republic, Department of Air Transport, doctorate, educational system, master, Prague, Technical University.

\section{Introduction}

Until the division of the Czech Republic, civil aviation specialists were prepared at the Faculty of Operation and Economics of Transport and Communications, University of Žilina. The Department of Air Transport was established at the Faculty of Transportation Sciences of CTU Prague on 1 March 2002. At present, it is the only Department in the Czech Republic that is oriented to the operational-technical and operational-economic problems of the civil aviation.

\section{European trends in the university education}

International co-operation in education started primarily with the involvement of the CR in the Socrates, Leonardo da Vinci and Tempus II educational programmes of the European Union. Such co-operation also began with projects in the area of strategy and control of the Committee for Science and University Education of the European Council. A starting point is also the Joint Declaration of Harmonization of the Development of the European System of University Education (Sorbonne Declaration). As for the issues of acknowledging of the education and its parts, it started from the Agreement of Acknowledging Qualifications in University Education in the European Area (Lisbon Agreement). The results of the World Conference on University Education held in Paris in October 1998 are also taken into consideration. There the World Declaration of University Education in the 21st century and the framework of priorities for changes and development in university education were accepted.

The structure of individual educational programmes is moving gradually toward the target that will enables a student to continue in further education immediately or after a certain period of time at either the same or another home or foreign university, always after meeting all the requirements of the relevant linking educational programme. The priorities of development in this area are therefore the module structure of educational programmes, use of all the possibilities of the credit system, which also enables changing the educational path, and the more consistant application of the three- 
level structure of education (bachelor's, master's, doctoral degree programmes). This intention is fully in accord with the processes of harmonization of university education in Europe, as defined in the Sorbonne Declaration and further developed in the Bologna Declaration of June 1999 [1].

The Sorbonne Declaration suggests an idea of harmonization of the university systems in Europe, especially regarding the harmonization of the educational schemes of undergraduate - bachelor's degrees - and graduate - master's or doctoral degrees and mobility of students and academic staff as a necessary part of European integration. The international mobility of students and teachers in the area of university education and all the steps leading to the harmonization of the system of education (introduction of ECTS, work on the harmonization of educational plans, activities leading to the facilitation of the process of mutual recognition of qualifications etc.) are supported in connection with this declaration.

\section{Obligations resulting from the membership in JAA}

At present, the Czech Republic is a full member of the Joint Aviation Authorities (JAA) in Europe. When organizing education, the starting point is the Joint Aviation Regulations (JAR) issued by the JAA according to the regulations of the EU in the wording accepted by the $\mathrm{CR}$, which represents obligatory legal regulations in the Czech Republic of law. It considers the following regulations above all:

- JAR-66 Certifying Staff

- JAR-145 Organizations Authorized to

Do Maintenance

- JAR-147 Approved Training of the Maintenance/Trial

- JAR-OPS 1 Business Air Transport (Aircraft)

- JAR-OPS 3 Business Air Transport (Helicopters)

- JAR-FCL 1 Competence of the Members of the Crew (Aircraft)

- JAR-FCL 2 Competence of the Members of the Crew (Helicopter)

- JAR-FCL 3 Competence of the Members of the Crew (Medical Examination)

\section{Education at the Faculty of Engineering of the Technical University of Brno}

The Institute of Aerospace Engineering, which prepares the engineers in a classical five-year university education in the specializations Aircraft Construction and Aircraft Traffic is part of the Faculty of Engineering Nowadays, within the framework of the transition to the three-level educational structure, there exists a bachelor's degree in Professional Pilot, and the Institute of
Aerospace Engineering works as an organization for the theoretical training of professional transport pilots in the integrated course according to the European regulations JAR-FCL 1 (FTO - Flying training organization) approved by the Authority for Civil Aviation of the Czech Republic.

\section{Education at the Faculty of Transportation Sciences, Czech Technical University in Prague}

\subsection{Objectives of the Department of Air Transport}

The Department of Air Transport was established at the Faculty of Transportation Sciences on 1 March 2002. The basic objective of the Department of Air Transport is the preparation of university specialists for civil aviation in the Czech Republic. Until the division of the Czech Republic, these specialists were prepared at the Department of Air Transport, Faculty of Operation and Economics of Transport and Communications, University of Žilina (former University of Transport and Communications Žilina). At present, it is the only department in the Czech Republic that is oriented to operational-technical and operational-economic problems in civil aviation.

In accord with the Bologna Agreement, education at the Czech Technical University in Prague is gradually moving to the three-tier system [2]. Education for the needs of the civil aviation is also adapted to these requirements (See the scheme attached).

\subsubsection{Profile of the graduate. Graduate from the Bachelor degree programme "Professional pilot"}

The aim of study is to provide the necessary theoretical training so that the student can take practical air training in a chosen flight school FTO together with theoretical training at the Czech Technical University in Prague up to the level of essential qualification that entitles them to the function of the second pilot in a multiengine, multipilot aircraft in the air transport business. After finishing the relevant flight training, the applicant has to pass an exam of skill according to the regulation JAR-FCL.

The graduate is prepared for the activities of a professional pilot in accord with European regulations, which entitles them after passing the standard exam to be a pilot in an arbitrary type of aircraft in an arbitrary state of the European Union. The programme was introduced in the academic year 2002/03. 


\subsubsection{Graduate from the Bachelor degree programme "Technology of aircraft maintenance"}

The main goal of this programme is to give a university degree in civil aviation and give theoretical knowledge in accordance with JAR 66.

This programme has subsequent specializations: B1 - Line maintenance - mechanical

- B1.1 - Aeroplanes Turbine

- B1.2-Aeroplanes Piston

B2 - Line maintenance - avionic

JAR 147 requirements for the basic training course for subcategory B1 or B2 specifies a minimum of 2,400 hours $(60 \mathrm{~min})$. Knowledge training should be between $50 \%-60 \%$ of approved basic training (1200-1440 hrs á 60 min, it is 1600-1920 hrs á 45 min). The Bachelor's degree programme exceeds the required 1,920 hours of knowledge training by 166 hours and the required 960 hours of practical training by $32 \mathrm{hrs}$.

The students of this programme are provided tuition by experienced tutors from the CTU and professionals with a wide range of work and practical experince.

The Bachelor's degree programme is a basic training course. Graduates receive basic knowledge and practical knowledge according to JAR 66 and JAR 147 requirements. FTS is approved MTO and therefore the examinations passed during the studies will be accepted by the Aviation Autority, which entitles a graduate to serve in any state of the European Union.

Practical training takes place in the approved organisation. The programme was introduced in the academic year 2004/05.

\subsubsection{Graduate from the Bachelor's degree programme "Air transport"}

Study is oriented to the perfect learning of the problems of civil air transport, of the problems of airports and of the modern trends of the development of the airports, learning of the systems of air traffic management and communication, navigation and surveillance. Graduates have to be familiar with the problems of the operation and economics of air transport. Attention is paid to the problems of the maintenance of aircraft and to quality in the civil aviation, with the knowledge at the level of present European and world regulations, the graduate is prepared to serve in civil aviation organizations. In a similar way, graduates are prepared to pass exams at the Civil Aviation Authority in the area of business air transport according to the regulation JAROPS.

Graduates will assert themselves in a wide range of traffic, technical and economic functions in the area of the air transport at the medium level of control. The programme was introduced in the academic year 2003/04.
4.1.4. Graduate from the Master's degree programme "Air transport operation and control"

Study is oriented towards the education of university-educated specialists, primarily for the higher directive functions in civil aviation of the Czech Republic. The contents of the degree are linked to the bachelor's degree (to the major Air transport above all) and meet the qualification requirements, that have been newly created and unified for the states of the EU and are anchored in the regulations issued by the Joint Aviation Authorities (JAA).

The graduates will assert themselves in a wide range of middle and high management in traffic, technical, and economic functions in the area of air transport. They are able to hold responsible positions in the medium and higher management levels of air carriers (Czech Airlines - ČSA and others), they can hold supervisory posts in the Czech Airport Authority or Air Traffic Control of the CR, or they can hold management functions in the Civil Aviation Authority of the CR or Union for the Civil Aviation Ministry of Transport.

\subsubsection{Graduate from the Doctoral degree programme "Air transport operation and control"}

The object of the doctoral degree programme "Air transport operation and control" is to develop the independent creative skill of the students and the methods of scientific research so that they can further develop the issues of the branch both theoretically and practically.

The doctoral programme is oriented towards scientific research and the independent creative work of the doctoral student especially in these areas:

- development of air transport systems on the principles of permanently kept mobility,

- european air traffic policy,

- development of evaluation methods for air traffic systems utility,

- development of modern logistic systems,

- modelling of technological processes,

- development of systems of communication, navigation and surveillance.

The graduate can find self-assertion in creative solutions to the issues of technology and management in air traffic, in research institutes or in university institutions. A doctoral graduate can also find work as a hig-level manager or economist of air traffic, in traffic and project organizations, in the offices of state authority when finding solutions to complicated and complex problems of air traffic technology and management. 


\subsection{Project approach to the university education}

There is a narrower specialization for students within the framework of the educational programme at the Faculty of Transportation Sciences, in which the students are involved in the projects. The Department of Air Transport has been ensuring these projects since the 2002/03 academic years:

\subsubsection{European approach to the maintenance of the aircraft}

The project is oriented towards the present European trends in the technical maintenance of aircraft and in the preparation of the staff for maintenance. The contents of the project will be gradually oriented towards these areas: system of educating maintenance staff according to JAR66; suggestions for educating staff in the conditions of the CR; regulations JAR-145 and JAR-147, which specify the service of maintenance; application of European regulations to small maintenance services in the $\mathrm{CR}$; and making suggestions on methods for the acknowledgement of the maintenance.

\subsubsection{Quality in cvil aviation}

This project is oriented towards the present European trends in quality. The contents of the project will be gradually oriented towards these areas: becoming familiar with the ISO 9000: 2000 norms, the requirements of the European JAR regulations for quality in civil aviation, SW for the quality achievable in the CR and its applications to civil aviation, methods for the creation of a quality system for air transporters and airports, quality of the conditions in flight schools, maintenance, and problems of security in civil aviation.

\subsubsection{Modern trends in the development of the airports}

This project is oriented towards the present European trends in the development of aircraft. The contents of the project will be gradually oriented towards these areas: judgement of the structure of the international airport network in the $\mathrm{CR}$ with the surrounding European region taken into consideration, problems of the territorially planned documentation for airports, gradual certification of the international airports in accord with Annex 14/I, problems of the safe zones of the airports, assessment regarding the acquisition of the safe zones status and 3D depiction in maps, creation of the 3D safe zones models, judgement of the creation of the water airports, and ecological aspects of airports.

\subsubsection{Systems of air traffic management and CNS}

This project is oriented towards the present European trends of air traffic management and communication, navigation and surveillance (CNS). The contents of the project will be gradually oriented towards these areas: problems of the air traffic control according to the documents of ICAO, conception of the future Europe Open Sky systems, modern CNS systems, problems in the management of stream of air traffic, problems in the flexibile use of the airspace, and automated systems of air traffic control systems, problems in the management of stream of air traffic, problems in the flexibile use of the airspace, and automated systems of air traffic control.

\subsubsection{Air transport operation and economics}

The project is oriented towards present European trends in air transport economics and traffic. The contents of the project will be gradually oriented towards these areas: position and tasks of transport in the national economy, characteristics of the individual transport majors, tasks of air transport in the transportational structure, organization and control of civil aviation, national and multinational organizations, technical traffic of aircraft, air transportation, contracts and tariffs used in air transport, and special air work of the Division of the Economic Disciplines; basic microeconomic laws; segmentation of the market and the possibilities of enterprise; economics of air transport; economic indicators of the economy in air transport; and business activities in air transport.

\section{Conclusion}

A well-balanced university education for operationally economic and operationally technical areas of civil aviation of the Czech Republic has been achieved by forming the model of university education that is described in this article. The issue of the aircraft construction is not included in this version. The model has been fully accredited by the Ministry of Education and is in accordance with the European trends in university education.

\section{References}

1. Joint declaration of the European Ministers of Education convened in Bologna on 19 June 1999. 1999.

2. KULČÁK, L. University for the Civil Aviation of the Czech Republic. Problemi informatizacii ta upravlenija. Kiev, 2003, vol 1, p. 172-177. 
Current structure of university education for the civil aviation in the CR:

At the Faculty of Transportation Sciences,

Czech Technical University in Prague

\section{Doctoral \\ degree \\ programme}

\section{Master's degree programme}

EP: Engineering and technology in transport and communications

M: Air transport management and control

Standard time of study 3 years

EP: Engineering and technology in transport and communications

M: Air transport management and control

Standard time of study 2 years

Projects:

Linking to the bachelor;s degree programme

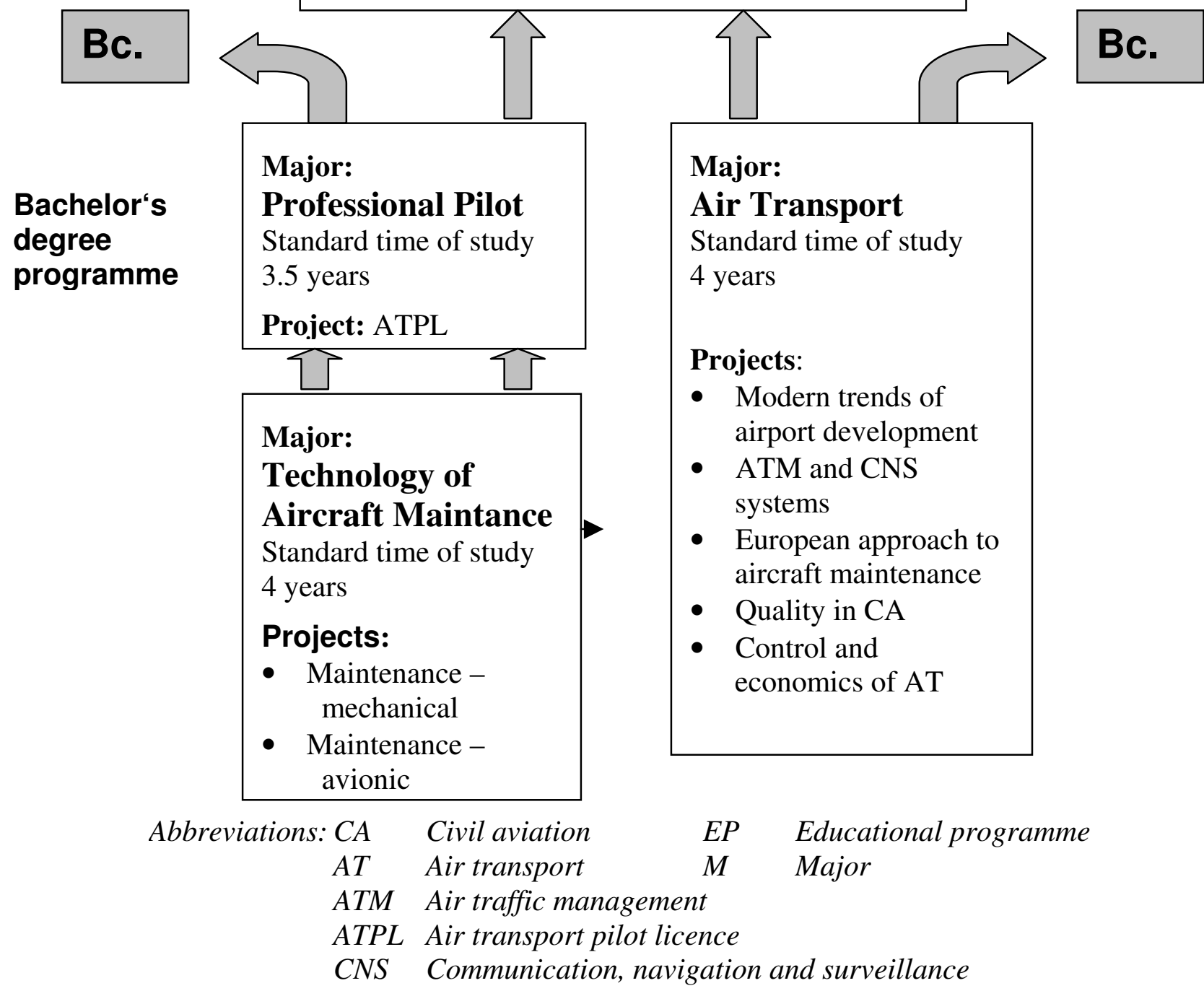

